\title{
Restoration of ecosystem carbon and nitrogen storage and microbial biomass after grazing exclusion in semi-arid grasslands of Inner Mongolia
}

\author{
Xing $\mathrm{Wu}^{\mathrm{a}}$, Zongshan $\mathrm{Li}^{\mathrm{a}}$, Bojie $\mathrm{Fu}^{\mathrm{a}}{ }$, Wangming Zhou ${ }^{\mathrm{b}}$, Huifeng Liu ${ }^{\mathrm{a}}$, Guohua Liu ${ }^{\mathrm{a}, *}$ \\ a State Key Laboratory of Urban and Regional Ecology, Research Center for Eco-environmental Sciences (RCEES), Chinese Academy of Sciences, P.O. Box 2871, \\ 100085 Beijing, China

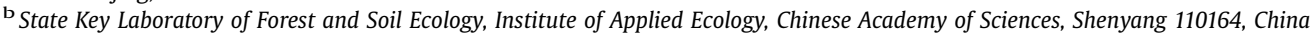

\section{A R T I C L E I N F O}

\section{Article history:}

Received 3 April 2014

Received in revised form 13 August 2014

Accepted 7 September 2014

Available online $\mathrm{xxx}$

\section{Keywords:}

Grazing exclusion

Returning Grazing Lands to Grasslands

(RGLG) project

Carbon and nitrogen storage

Soil microbial biomass

Restoration

Semi-arid grassland

\begin{abstract}
A B S T R A C T
The semi-arid grasslands in Inner Mongolia have been degraded as a result of long-term grazing and poor grassland management. A series of ecological restoration strategies have been implemented to enhance the ecosystem services of China's grasslands. To understand the response of ecosystem $\mathrm{C}$ and $\mathrm{N}$ to grazing exclusion within a nationwide conservation project-Returning Grazing Lands to Grasslands (RGLG), the C and $\mathrm{N}$ storages in different parts of the plant-soil system as well as soil microbial biomass carbon (MBC) and nitrogen (MBN) contents were determined and compared between three grazing exclusion sites (6 years) and the paired adjacent grazing sites in the Hulunbuir grassland of Inner Mongolia. Our results showed that the exclusion of grazing for 6 years resulted in significant increases of ecosystem biomass and soil $\mathrm{C}$ and $\mathrm{N}$ contents, leading to a substantial restoration of ecosystem $\mathrm{C}$ and $\mathrm{N}$ storage. The average $\mathrm{C}$ and $\mathrm{N}$ accumulation rates in the whole ecosystem were $173.6 \mathrm{~g} \mathrm{C} \mathrm{m}^{-2}$ year $^{-1}$ and $19.8 \mathrm{~g} \mathrm{~N} \mathrm{~m}^{-2}$ year $^{-1}$, respectively. The accumulation of $\mathrm{C}$ and $\mathrm{N}$ in soil contributed to more than $87.6 \%$ and $98.2 \%$ of the increases in ecosystem $C$ and $N$, respectively, indicating that the restoration of ecosystem $C$ and $N$ were mainly due to the increase of $\mathrm{C}$ and $\mathrm{N}$ in soil after exclusion of grazing. The higher MBC and $\mathrm{MBN}$ in exclosure sites than grazing sites might be partly because of the enhanced organic matter inputs from plant litter and root exudates. The significant correlations between soil organic matter and microbial biomass suggested that soil microbial biomass could be a sensitive indicator of the soil C and $\mathrm{N}$ dynamics. These results indicated that exclusion of grazing pressure within the RGLG project is an effective restoration approach to control grassland degradation in this region. However, more comprehensive multidisciplinary studies are needed to evaluate the effectiveness of the RGLG project and to improve the management strategies for grassland restoration.
\end{abstract}

(c) 2014 Elsevier B.V. All rights reserved.

\section{Introduction}

Motivated by the anthropogenic-driven global change and the rapid increase in atmospheric concentrations of greenhouse gases, extensive work has been conducted to improve our understanding of global carbon $(\mathrm{C})$ and nitrogen $(\mathrm{N})$ cycles and to identify the possibility of various potential sinks (Fornara and Tilman, 2012; Lal, 2010; Pineiro et al., 2010). The role of soil in mitigating the atmospheric $\mathrm{CO}_{2}$ and in increasing the carbon sink has received considerable attention in recent years (Cui et al., 2005; Lal, 2004; Medina-Roldan et al., 2012; Reeder et al., 2004), whereas only a few

\footnotetext{
* Corresponding author. Tel.: +86 10 62849102; fax: +861062849102.

E-mail addresses: xingwu@rcees.ac.cn (X. Wu), ghliu@rcees.ac.cn (G. Liu).
}

studies were focused on the carbon and nitrogen storage potential in the whole plant-soil system, especially for the grassland (He et al., 2008; Li et al., 2012; Qiu et al., 2013). Grasslands are an important part of global $\mathrm{C}$ and $\mathrm{N}$ cycles, as they cover approximately one quarter of the terrestrial surface and account for more than $20 \%$ of total terrestrial productions (Scurlock and Hall, 1998; Wu et al., 2010). Globally, grasslands store more than $10 \%$ of terrestrial biomass $C$ and $10-30 \%$ of soil organic C (SOC), and they have been reported to sequester $C$ in soil at a rate of $0.5 \mathrm{PgC}_{\text {year }}{ }^{-1}$, which is about one-fourth of the potential C sequestration in the world soils (Follett and Reed, 2010; Qiu et al., 2013). However, grazing by domestic livestock, one of the major human activities in grassland worldwide, has been found to cause grassland degradation and have significant effects on $\mathrm{C}$ and $\mathrm{N}$ cycles and storage (Giese et al., 2013; Mcsherry and Ritchie, 2013). 
Restoring the degraded grassland ecosystem by implementing appropriate management practices might have a high $\mathrm{C}$ sequestration potential.

Grasslands cover about $40 \%$ of the total land area in China, which account for about $6-8 \%$ of the total world grassland area and contain $9-16 \%$ of the world's total grassland carbon stocks $(\mathrm{Ni}$, 2002). However, by the end of the twentieth century, most of these grasslands were degraded as a consequence of a rapid expansion in livestock numbers and economic reforms initiated in the late 1970s, especially for the semi-arid grasslands in Inner Mongolia (He et al., 2008; Wu et al., 2010). Given the vast area of grasslands in China, large scale degradation of grasslands is likely to have profound impacts on the global $\mathrm{C}$ and $\mathrm{N}$ cycles and climate change (Liu and Diamond, 2005; Wang et al., 2011). In order to control the degradation and enhance the ecosystem services of China's grasslands, a series of improved grassland management strategies have been implemented in recent years. Practically, a nationwide conservation project-Returning Grazing Lands to Grasslands (RGLG) has been implemented in temperate and alpine grasslands in eight provinces or autonomous regions since 2003 to restore the vegetation and soil, improve grassland productivity and promote the equilibrium between ecological protection and socio-economic development. Until 2012, more than 60 million hectare degraded grasslands were included in the nationwide RGLG project (Xiong et al., 2014). Grazing exclusion, which has been extensively employed throughout the world to improve grassland service, was one of the most common practices for grassland restoration in this project. Several case studies have shown that grazing exclusion could be effective in changing plant community and diversity (Cheng et al., 2011; Medina-Roldan et al., 2012), in improving soil physical and chemical properties (Mekuria et al., 2007; Pei et al., 2008), and in reducing soil degradation (Jeddi and Chaieb, 2010; Luan et al., 2014). However, there are few published studies on the effects of grazing exclusion on the ecosystem carbon and nitrogen storage in semi-arid grassland of Inner Mongolia, especially referring to the RGLG project.
Soil microbial biomass was found to be a sensitive indicator of the dynamics of soil C and N cycles (Giese et al., 2013; Liu et al., 2012). Moreover, litter composition, soil carbon pool and microbial biomass are highly interlinked during carbon accumulation by soil (Fließbach and Mader, 2000; Shrestha and Stahl, 2008). However, there is little information about the effects of grazing exclusion on microbial biomass carbon (MBC) and nitrogen (MBN), and the underlying mechanisms involved between soil $\mathrm{C}$ and $\mathrm{N}$ dynamics and microbial biomass still remain unclear. Therefore, it is essential to acquire an understanding of how soil microbial biomass response to grazing exclusion and the relationships between soil organic matter and microbial biomass.

In this study, the $\mathrm{C}$ and $\mathrm{N}$ storages in different parts of the plantsoil system, the concentrations of soil MBC and MBN, and the relationships between soil organic matter and microbial biomass were compared between three fenced sites and the paired adjacent grazed sites in the Hulunbuir grassland of Inner Mongolia. This study tested the hypothesis that grazing exclusion could enhance ecosystem $\mathrm{C}$ and $\mathrm{N}$ storage, soil microbial biomass, and that soil microbial biomass could be an indicator of the soil $\mathrm{C}$ and $\mathrm{N}$ dynamics induced by grazing exclusion. The specific objectives of this study were to (1) investigate the effects of grazing exclusion on the $\mathrm{C}$ and $\mathrm{N}$ storages in soil and ecosystem biomass, and soil MBC and MBN; (2) evaluate the potential relationships between soil organic matter and microbial biomass.

\section{Materials and methods}

\subsection{Study area}

This study was conducted in the Hulunbuir grassland $\left(47^{\circ} 05^{\prime}-\right.$ $53^{\circ} 20^{\prime} \mathrm{N}, 115^{\circ} 31^{\prime}-126^{\circ} 04^{\prime} \mathrm{E}$ ), which is a representative semi-arid grassland of Inner Mongolia. The study area is located in the western part of Daxing'anling Mountains with a relatively flat topography ranging from $650-700 \mathrm{~m}$ ASL. This area has a temperate continental semi-arid monsoon climate with a mean

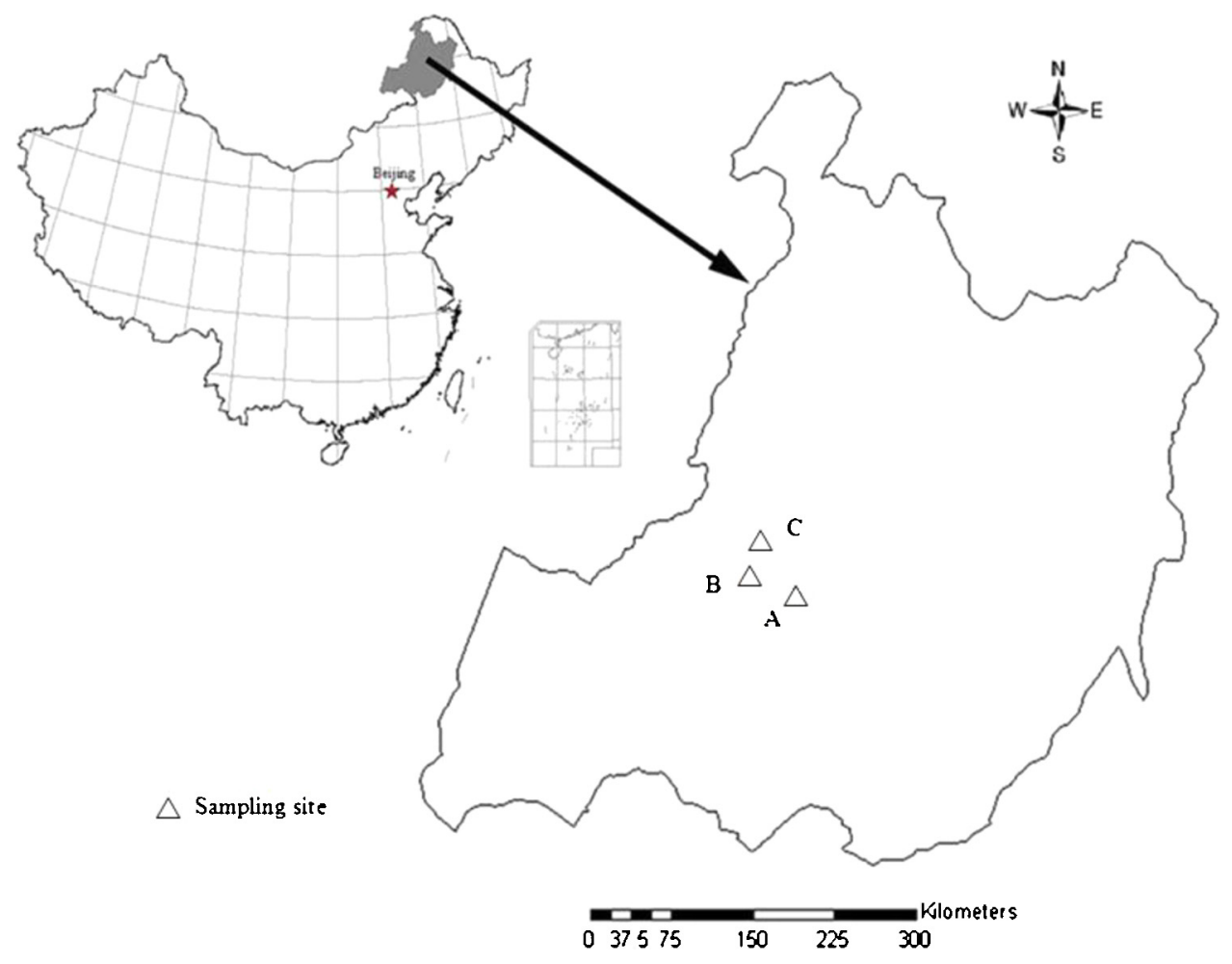

Fig. 1. Location of the sampling sites. 
annual precipitation of $339 \mathrm{~mm}$, of which about $60 \%$ falls from June to September, and a mean annual air temperature of $-2.2^{\circ} \mathrm{C}$, respectively. The meteorological data were obtained from Hailaer Weather Station, which is about $30 \mathrm{~km}$ from our experimental sites. Edaphic characteristics (physical traits and chemical nutrition) are heterogeneous and the main soil types are chernozem and chestnut (Wu et al., 2013). Gradually decreasing precipitation from east to west results in floristically distinct land cover types in this region, including arid steppe (dominated by Allium polyrrhizum), typical steppe (dominated by Serratula centauroides,Salsola collina, Chenopodium glaucum and Carex korshinskyi) and meadow steppe (dominated by Aneurolepidium chinense, Stipa baicalensis and $C$. korshinskyi) (Wu et al., 2013).

\subsection{Field investigation and sampling}

Three experimental sites of meadow steppe with similar soil type, plant species and land use history were selected in our study (Fig. 1). The distances between each experimental site were about 20-50 km. At each site, plots were established to be paired, where a grazing exclusion plot occurred directly adjacent to a long-term free grazing plot. The distance between plots in each site ranged approximately $100-200 \mathrm{~m}$. All the paired plots have the same soil type and similar physiographic conditions (slope degree, altitude and topography). The grazing exclusion plots were fenced since 2005 at all three sites due to the RGLG project (ranging from 20 to 35 ha). The location and the main characteristics of each site are shown in Table 1 . The average ground covers were about $85 \%$ and $40 \%$ for grazing exclusion and long-term grazing plots, respectively. Vegetation measurements and soil sampling were carried out in August 2011, which is a typical period of peak aboveground biomass. In each plot, 5 sampling subplots $(1 \mathrm{~m} \times 1 \mathrm{~m})$ were established at a $15-\mathrm{m}$ interval along a random transect. Within each subplot, the aboveground biomass and surface litter were harvested and collected separately. After the litter layer was removed, the belowground biomass was sampled from 5 sampling points down to a depth of $30 \mathrm{~cm}$ in the main rooting zone using a soil auger $(5 \mathrm{~cm}$ in diameter) in each subplot. Soil samples were collected using a soil sampler ( $4 \mathrm{~cm}$ diameter) from 4 depths: $0-10$, 10-20, 20-30 and 30-40 cm. A composite soil sample was obtained for each depth using the soil collected at 3 sampling points in each subplot. Therefore, within each experimental plot, 5 composite soil samples were collected for each soil depth, yielding a total of 120 composite soil samples for all plots and depths. After removing roots and stones, each composite soil sample was divided into two parts, and one was directly sealed by zip lock bags and stored in refrigerated conditions $\left(4^{\circ} \mathrm{C}\right)$ up to one week to analyze the MBC and MBN. Soil bulk density was measured using soil cores $\left(100 \mathrm{~cm}^{3}\right.$ volume) obtained from the four depths, with 5 replicates for each plot.

\subsection{Laboratory analysis}

In the laboratory, the belowground biomass was carefully washed to remove the soil. Before analysis, all aboveground and belowground biomass samples were oven-dried at $60^{\circ} \mathrm{C}$ for $48 \mathrm{~h}$, and weighted. Soil samples were air-dried at room temperature and hand-sieved through a 2-mm sieve to remove roots and other debris. Each soil sample and biomass sample was ground to pass a $0.2-\mathrm{mm}$ sieve before determination of the $\mathrm{C}$ and $\mathrm{N}$ concentrations. The organic $C$ concentrations in soil and biomass samples were determined using the Walkley-Black dichromate oxidation procedure (Nelson and Sommers, 1982). The total N concentrations in soil and biomass samples were measured using the modified Kjeldahl wet digestion procedure (Gallaher et al., 1976). The pH of $0-10 \mathrm{~cm}$ soil samples were measured in a $1: 2.5$ water suspension.

The $\mathrm{C}$ and $\mathrm{N}$ storage in aboveground and belowground biomass was the result of the mass of a given biomass component $\left(\mathrm{g} \mathrm{m}^{-2}\right)$ multiplied by its respective mean concentration $\left(\mathrm{g} \mathrm{kg}^{-1}\right)$. The soil C and $\mathrm{N}$ storages per unit area by volume in soil to a depth of $40 \mathrm{~cm}$ (ES in $\mathrm{g} \mathrm{m}^{-2}$ ) were determined according to the method of Li et al. (2012) by using element concentration (EC in $\mathrm{g} \mathrm{kg}^{-1}$ ), soil bulk density (BD in $\mathrm{g} \mathrm{cm}^{-3}$ ) and soil depth of each soil sample $\left(T_{i}\right.$ in $\left.\mathrm{cm}\right)$ :

$\mathrm{ES}=10 \sum_{i=1}^{4}\left(\mathrm{EC}_{i} \times \mathrm{BD}_{i} \times T_{i}\right)$

where 10 represents the unit conversion factor and $T_{i}(i=1,2,3,4)$ represents the thickness of soil sampling depth $i$.

The chloroform fumigation-extraction method described in detail by Vance et al. (1987) and Wu et al. (2010) was used for quantifying $M B C$ and MBN. Briefly, soil samples were divided in paired subsamples of $30 \mathrm{~g}$ each. One subsample was immediately extracted with $60 \mathrm{ml} 0.5 \mathrm{M} \mathrm{K}_{2} \mathrm{SO}_{4}$ on a rotary shaker at $150 \mathrm{rpm}$. The second subsample was fumigated under chloroform vapor for $24 \mathrm{~h}$ in a desiccator followed by ten vacuum/purge cycles and then extracted. Extracts were filtered using a $0.45 \mu \mathrm{m}$ syringe filter and analyzed for total organic carbon and total nitrogen. Correction factors (0.54 for MBN and 0.379 for MBC, Vance et al., 1987) were used in our calculations.

\subsection{Data and statistical analyses}

Statistical analyses were carried out with SPSS 13.0 and SigmaPlot 2000 (SPSS Inc., Chicago, USA). All data were expressed as mean \pm 1 stand error of mean. An analysis of variance (ANOVA) was used to evaluate the effect of grazing exclusion on plant and soil variables, their resultant $\mathrm{C}$ and $\mathrm{N}$ storages, and $\mathrm{MBC}$ and $\mathrm{MBN}$. Analyses of significant differences in SOC, TN, MBC and MBN concentrations among different soil depths were carried out using LSD tests. Correlations between SOC, TN, C/N, MBC and MBN were calculated using Pearson coefficient. Regression analysis was used to assess the relationship between $\mathrm{C}$ and $\mathrm{N}$ storages in soil and biomass.

\section{Results}

\section{1. $C$ and $N$ in vegetation}

Grazing exclusion significantly increased the plant coverage, aboveground and litter biomass at all three sites (Table 1 and

Table 1

Main characteristics of the study sites (mean $\pm \mathrm{SE}$ ).

\begin{tabular}{|c|c|c|c|c|c|c|c|c|}
\hline Sampling sites & Coordinates & Dominant species & Treatment & Altitude (m) & Ground coverage (\%) & $\mathrm{BD}\left(\mathrm{g} \mathrm{cm}^{-3}\right)$ & $\mathrm{pH}$ & Land use history \\
\hline \multirow[t]{2}{*}{ Site A } & $49^{\circ} 04.3^{\prime} \mathrm{N}, 120^{\circ} 18.5^{\prime} \mathrm{E}$ & Aneurolepidium chinense & Grazing & 685.4 & 35 & $1.17 \mathrm{a}$ & $7.1 \pm 0.1 \mathrm{a}$ & Long-term grazing \\
\hline & & Carex pediformis & Exclosure & 684.8 & 88 & $1.11 \mathrm{~b}$ & $7.0 \pm 0.1 \mathrm{a}$ & Fenced since 2005 \\
\hline \multirow[t]{2}{*}{ Site B } & $49^{\circ} 26.4^{\prime} \mathrm{N}, 119^{\circ} 30.1^{\prime} \mathrm{E}$ & Aneurolepidium chinense & Grazing & 664.3 & 42 & $1.20 \mathrm{a}$ & $7.3 \pm 0.2 \mathrm{a}$ & Long-term grazing \\
\hline & & & Exclosure & 664.1 & 83 & $1.18 \mathrm{a}$ & $7.1 \pm 0.1 \mathrm{a}$ & Fenced since 2005 \\
\hline \multirow[t]{2}{*}{ Site C } & $50^{\circ} 10.2^{\prime} \mathrm{N}, 119^{\circ} 37.3^{\prime} \mathrm{E}$ & Aneurolepidium chinense & Grazing & 669.5 & 39 & $1.19 \mathrm{a}$ & $7.2 \pm 0.1 \mathrm{a}$ & Long-term grazing \\
\hline & & & Exclosure & 670.1 & 85 & $1.16 \mathrm{a}$ & $7.1 \pm 0.1 \mathrm{a}$ & Fenced since 2005 \\
\hline
\end{tabular}

Note: BD: Bulk density of 0-10 cm soil depth; Different lowercase letters indicate significant differences between different treatments $(P<0.05)$. 


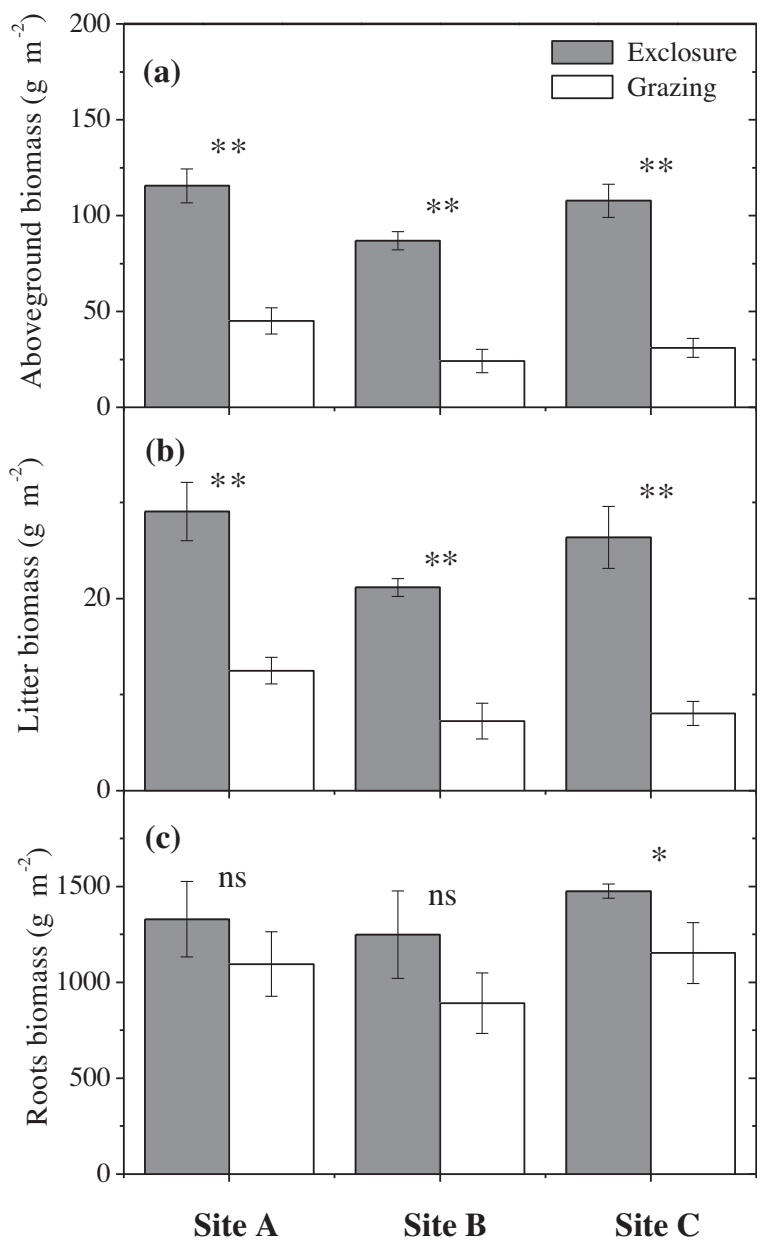

Fig. 2. The effects of grazing exclusion on aboveground biomass (a), litter biomass (b) and roots biomass (c) in different sampling sites. Error bars are the standard error of the mean, $\left({ }^{*}: P<0.05\right.$; $^{* *}: P<0.01$; ns: $\left.P>0.05\right)$.

Fig. 2). The amount of aboveground and litter biomass in the grazing plots ranged from 24.1 to 45.1 and 7.2 to $12.5 \mathrm{~g} \mathrm{~m}^{-2}$, respectively, which were approximately 2-3 times lower than those in the grazing exclusion plots $(P<0.01)$. Although exclusion of grazing also generally resulted in an increase of root biomass, statistical difference $(P<0.05)$ was only showed by site $C$ (Fig. 2(c)). The mean ratios of aboveground to root biomass for grazing exclusion and long-term grazing plots were around 0.1 and 0.04 , respectively.

As was the case with the amount of plant biomass, the $C$ and $\mathrm{N}$ storages in aboveground and litter biomass were significantly increased after the exclusion of grazing $(P<0.05$, Fig. 3$)$. The average $C$ storages in aboveground and litter biomass in grazing exclusion plots were $42.5 \pm 2.4$ and $11.6 \pm 0.9 \mathrm{~g} \mathrm{C} \mathrm{m}^{-2}$, respectively, which were about 2.79 and 2.87 times higher than those in adjacent grazing plots. The average $\mathrm{N}$ storages in aboveground and litter biomass were $1.51 \pm 0.09$ and $0.42 \pm 0.01 \mathrm{~g} \mathrm{~N} \mathrm{~m}^{-2}$ for the grazing exclusion plots, and $0.55 \pm 0.05$ and $0.16 \pm 0.01 \mathrm{~g} \mathrm{~N} \mathrm{~m}^{-2}$ for the long-term grazing plots, respectively. Similar to the root biomass, no significant differences in both $\mathrm{C}$ and $\mathrm{N}$ storage in root biomass were found between grazing and exclosure (Fig. 3(C)). However, root biomass accounted for a relatively large proportion of the total ecosystem biomass $\mathrm{C}$ and $\mathrm{N}$ storage, amounting to 91.2 and $82.3 \%$ of the total in grazing exclusion plots, respectively, versus 96.1 and $92.0 \%$ in the grazing plots. The total ecosystem biomass $\mathrm{C}$ and $\mathrm{N}$ in grazing exclusion

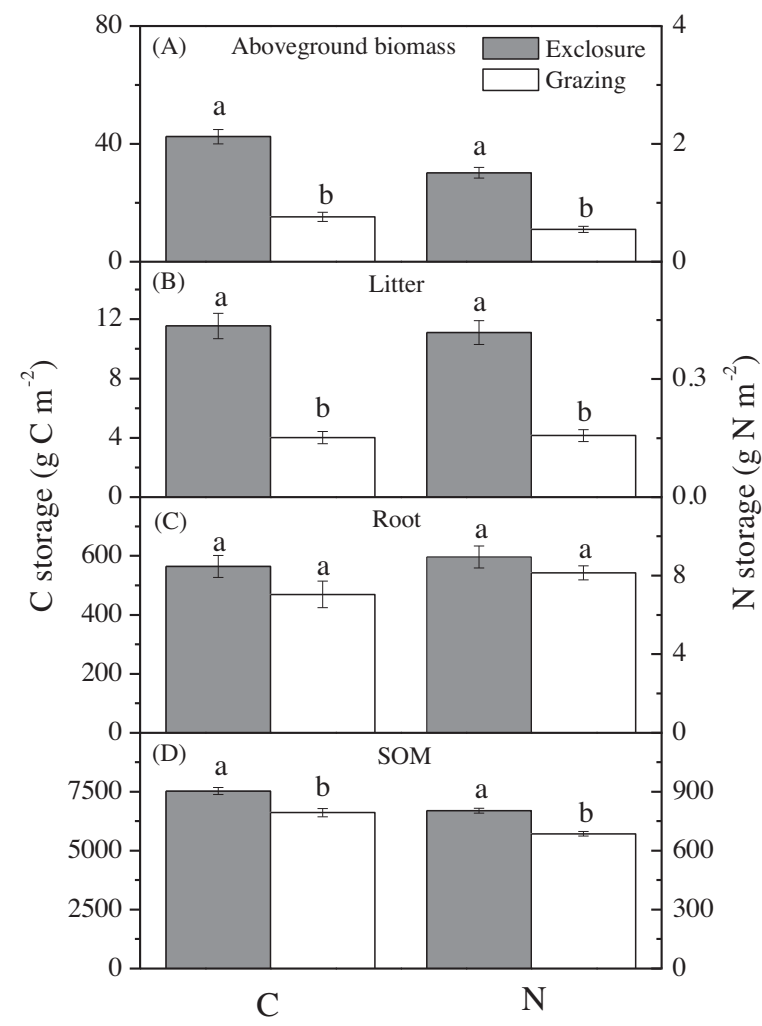

Fig. 3. C and N storages in aboveground biomass (A), litter (B), root (C) and SOM (D, top $40 \mathrm{~cm}$ layer) for grazing and exclosure sites. Means $( \pm \mathrm{SE}, N=15)$ with different letters differ at $P<0.05$ between grazing and exclosure sites.

plots were $617.7 \pm 39.7 \mathrm{~g} \mathrm{C} \mathrm{m}^{-2}$ and $10.9 \pm 0.6 \mathrm{~g} \mathrm{~N} \mathrm{~m}^{-2}$, respectively, which were 1.26 and 1.23 times higher $(P<0.05)$ than those in long-term grazing plots.

\section{2. $C$ and $N$ in soil}

Fencing the grasslands generally resulted in a decrease of soil bulk density and $\mathrm{pH}$, but statistical difference of bulk density $(P<0.05)$ was only showed by the soils from site A (Table 1$)$. In both grazing and exclosure plots at all three sites, soil TN and SOC concentrations were generally significantly declining with soil depth (Table 2). Although the soil $\mathrm{C} / \mathrm{N}$ ratios in both grazing and exclosure plots were also decreasing with soil depth, statistical difference $(P<0.05)$ was only showed by exclosure plots at 20 $30 \mathrm{~cm}$ depth. Grazing exclusion significantly increased soil TN and SOC concentrations down to a depth of $30 \mathrm{~cm}$, but the greatest difference in both variables occurred in the uppermost $10 \mathrm{~cm}$ of soil. The $\mathrm{C} / \mathrm{N}$ ratios were generally higher in grazing plots as compared to exclosure plots, however, no statistically significant difference was found between treatments.

The SOC storage in soil profile of $0-40 \mathrm{~cm}$ in grazing exclusion plots was $7529 \pm 150 \mathrm{~g} \mathrm{C} \mathrm{m}^{-2}$, which was about 1.14 times higher $(P<0.01)$ than that in long-term grazing plots. However, this significant difference of SOC storage mainly existed in the $0-30 \mathrm{~cm}$ soil depth (data not shown). Additionally, grazing exclusion also significantly increased the soil $\mathrm{N}$ storage down to $30 \mathrm{~cm}$ soil depth, leading to a substantial increase of the soil $\mathrm{N}$ storage in soil profile of $0-40 \mathrm{~cm}(P<0.01$, Fig. 3(D)). These results suggest that grazing exclusion has the potential to sequester $\mathrm{C}$ and $\mathrm{N}$ in soils, but shortterm (6 years) grazing exclusion might result in a higher $\mathrm{C}$ and $\mathrm{N}$ sequestration potential in the upper soil depths as compared to deeper soils. 
Table 2

$\mathrm{C}$ and $\mathrm{N}$ concentrations, $\mathrm{C} / \mathrm{N}$ ratios, $\mathrm{MBC} / \mathrm{SOC}$ and $\mathrm{MBN} / \mathrm{TN}$ ratios along soil profile at grazing and exclosure sites

\begin{tabular}{|c|c|c|c|c|c|c|c|c|c|c|}
\hline \multirow[t]{2}{*}{ Soil depth $(\mathrm{cm})$} & \multicolumn{2}{|c|}{ C concentration $\left(\mathrm{g} \mathrm{kg}^{-1}\right.$ soil $)$} & \multicolumn{2}{|c|}{$\mathrm{N}$ concentration $\left(\mathrm{g} \mathrm{kg}^{-1}\right.$ soil $)$} & \multicolumn{2}{|l|}{$\mathrm{C} / \mathrm{N}$ ratio } & \multicolumn{2}{|c|}{$\mathrm{MBC} / \mathrm{SOC}\left(\mathrm{mg} \mathrm{MBC}^{-1} \mathrm{SOC}\right)$} & \multicolumn{2}{|c|}{ MBN/TN (mg MBN g $\left.{ }^{-1} \mathrm{TN}\right)$} \\
\hline & Grazing & Exclosure & Grazing & Exclosure & Grazing & Exclosure & Grazing & Exclosure & Grazing & Exclosure \\
\hline $0-10$ & $17.9 \pm 0.7 \mathrm{Aa}$ & $22.5 \pm 0.6 \mathrm{Ab}$ & $1.8 \pm 0.04 \mathrm{Aa}$ & $2.3 \pm 0.06 \mathrm{Ab}$ & $9.9 \pm 0.2 \mathrm{Aa}$ & $9.7 \pm 0.2 \mathrm{Aa}$ & $23.9 \pm 1.2 \mathrm{Aa}$ & $23.5 \pm 1.0 \mathrm{Aa}$ & $33.2 \pm 1.3 \mathrm{Aa}$ & $28.5 \pm 0.8 \mathrm{Ab}$ \\
\hline $10-20$ & $13.8 \pm 0.5 \mathrm{Ba}$ & $16.2 \pm 0.4 \mathrm{Bb}$ & $1.4 \pm 0.03 \mathrm{Ba}$ & $1.7 \pm 0.03 \mathrm{Bb}$ & $9.6 \pm 0.2 \mathrm{Aa}$ & $9.4 \pm 0.2 \mathrm{ABa}$ & $24.0 \pm 1.4 \mathrm{Aa}$ & $24.7 \pm 1.0 \mathrm{Aa}$ & $29.1 \pm 1.6 \mathrm{Aa}$ & $27.3 \pm 1.3 \mathrm{ABa}$ \\
\hline $20-30$ & $11.3 \pm 0.3 \mathrm{Ca}$ & $12.3 \pm 0.2 \mathrm{Cb}$ & $1.2 \pm 0.02 \mathrm{Ca}$ & $1.4 \pm 0.02 \mathrm{Cb}$ & $9.5 \pm 0.2 \mathrm{Aa}$ & $9.1 \pm 0.1 \mathrm{Ba}$ & $22.2 \pm 0.9 \mathrm{Aa}$ & $24.9 \pm 1.4 \mathrm{Aa}$ & $24.7 \pm 1.5 \mathrm{Ba}$ & $24.2 \pm 1.5 \mathrm{Ba}$ \\
\hline $30-40$ & $10.1 \pm 0.3 \mathrm{Ca}$ & $10.8 \pm 0.3 \mathrm{Da}$ & $1.1 \pm 0.03 \mathrm{Ca}$ & $1.2 \pm 0.03 \mathrm{Da}$ & $9.5 \pm 0.3 \mathrm{Aa}$ & $9.3 \pm 0.3 \mathrm{ABa}$ & $20.9 \pm 1.2 \mathrm{Aa}$ & $23.1 \pm 1.6$ Aa & $20.4 \pm 1.6 \mathrm{Ca}$ & $17.2 \pm 1.4 \mathrm{Ca}$ \\
\hline Average & $13.3 \pm 0.4 \mathrm{a}$ & $15.4 \pm 0.3 \mathrm{~b}$ & $1.4 \pm 0.02 \mathrm{a}$ & $1.6 \pm 0.03 \mathrm{~b}$ & $9.7 \pm 0.2 \mathrm{a}$ & $9.4 \pm 0.1 \mathrm{a}$ & $22.8 \pm 0.6 \mathrm{a}$ & $24.0 \pm 1.1 \mathrm{a}$ & $26.9 \pm 1.1 \mathrm{a}$ & $24.3 \pm 1.0 \mathrm{a}$ \\
\hline
\end{tabular}

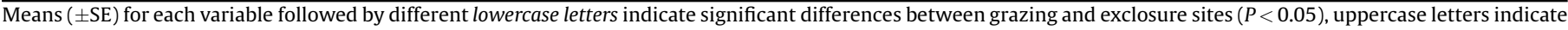
significant different among different soil depths $(P<0.05$, One-way ANOVA, LSD).

\section{3. $C$ and $N$ in the ecosystem}

The total ecosystem $\mathrm{C}$ and $\mathrm{N}$ storages in exclosure plots were $8147 \pm 186 \mathrm{~g} \mathrm{C} \mathrm{m}^{-2}$ and $813.2 \pm 12.8 \mathrm{~g} \mathrm{~N} \mathrm{~m}^{-2}$, respectively, which were about $14.7 \%$ and $17.1 \%$ greater than those in the adjacent grazing plots (Fig. 4(A)). For both grazing and exclosure plots, more than $92 \%$ of $C$ and $98 \%$ of $N$ were stored in the soil, while less than $1 \%$ of $\mathrm{C}$ and $\mathrm{N}$ were stored in the aboveground and litter biomass. However, grazing exclusion has shown to slightly reduce the proportion of soil $\mathrm{C}$ and $\mathrm{N}$ storages in the whole ecosystem (Fig. 4(B)). Moreover, the increase in $\mathrm{C}$ and $\mathrm{N}$ stored in soil contributed to more than $87.6 \%$ and $98.2 \%$ of the increases in ecosystem $\mathrm{C}$ and $\mathrm{N}$ storages. Based on the differences between grazing and exclosure plots, the soil $\mathrm{N}$ and SOC accumulation rates during the 6 years of exclosure averaged $152.1 \mathrm{gC}$ and $19.4 \mathrm{~g} \mathrm{~N} \mathrm{~m}^{-2}$ year $^{-1}$, respectively, whereas the biomass $\mathrm{C}$ and $\mathrm{N}$ accumulation rates were about $21.5 \mathrm{gC}$ and $0.4 \mathrm{~g} \mathrm{~N} \mathrm{~m}^{-2}$ year $^{-1}$, respectively. Additionally, the correlations between soil $\mathrm{C}$ storage
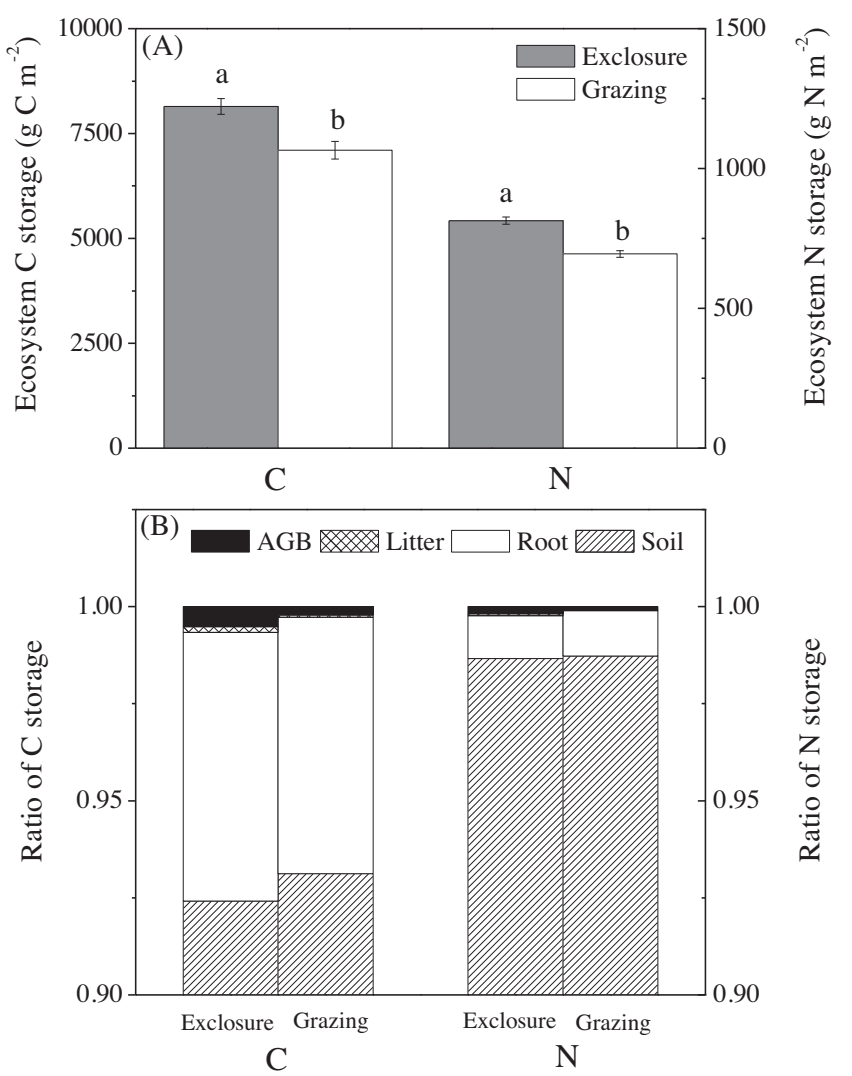

Fig. 4. Ecosystem $C$ and $N$ storages (mean $\pm S E, N=15$ ) for grazing and exclosure sites $(A)$, ratios of $C$ and $N$ storage in different parts for grazing and exclosure sites (B). Different letters indicate significant differences between treatments $(P<0.05)$. and the $\mathrm{C}$ storage in aboveground biomass (AGB), litter and root were positive and significant. Similarly, significant positive correlations were also observed between $\mathrm{N}$ storage in the soil and in the biomass (Fig. 5).

\section{4. $M B C$ and $M B N$}

In general, $\mathrm{MBC}$ and $\mathrm{MBN}$ concentrations were found to significantly decrease with soil depth in both grazing and exclosure plots (Fig. 6). However, no statistically significant difference in $\mathrm{MBC} / \mathrm{SOC}$ ratio was found among different soil depths, despite the fact that the $\mathrm{MBC} / \mathrm{SOC}$ ratio was also generally decreasing with soil depth (Table 2). In addition, statistical analysis of MBN/TN ratio along the soil profile showed significantly higher values $(P<0.05)$ in the top $20 \mathrm{~cm}$ soil depth as compared to deeper soil. Exclusion of grazing significantly increased the MBC concentrations down to $30 \mathrm{~cm}$ soil depth, leading to a substantial increase of MBC in the soil profile of $0-40 \mathrm{~cm}(P<0.05$, Fig. 6(a)). However, there were no significant differences between grazing and exclosure plots in MBN concentrations along the soil profile (Fig. 6(b)). Moreover, statistical analysis showed no overall significant difference in $\mathrm{MBC} / \mathrm{SOC}$ and MBN/TN ratios between grazing and exclosure plots (Table 2).

\subsection{Relationships among SOC, TN, C/N, MBC and $M B N$}

In both grazing and exclosure plots, SOC and TN exhibited extremely strong positive correlations $(P<0.001)$. Soil $\mathrm{C} / \mathrm{N}$ ratios generally showed significant positive correlations with SOC $(P<0.01)$, but weak correlations with TN in both treatment plots. Similarly, soil $\mathrm{C} / \mathrm{N}$ ratios exhibited significant positive correlations with MBC $(P<0.01)$, but generally weak correlation with MBN (Table 3). Moreover, MBC and MBN concentrations also showed significant positive correlations with SOC and TN in both treatment plots $(P<0.01)$.

\section{Discussion}

\subsection{Effects of grazing exclusion on ecosystem $C$ and $N$ storage and distribution}

Our study showed that the 6 years grazing exclusion had resulted in significant increases of $\mathrm{C}$ and $\mathrm{N}$ storage in aboveground and litter biomass, which were in agreement with several previous studies (He et al., 2008; Li et al., 2012; Ward et al., 2007). These increases in storage were mainly due to the significant recovery of aboveground and litter biomass after the exclusion of grazing. The reduced perturbation had a direct effect on aboveground and litter biomass demonstrating that grazing exclusion is an effective practice to improve vegetation recovery in degraded grassland (Jeddi and Chaieb, 2010 Zhou et al., 2011). These results suggest that grazing exclusion has the potential to store $\mathrm{C}$ and $\mathrm{N}$ in aboveground and litter biomass in semi-arid grassland of Inner Mongolia. Qiu et al. (2013) 


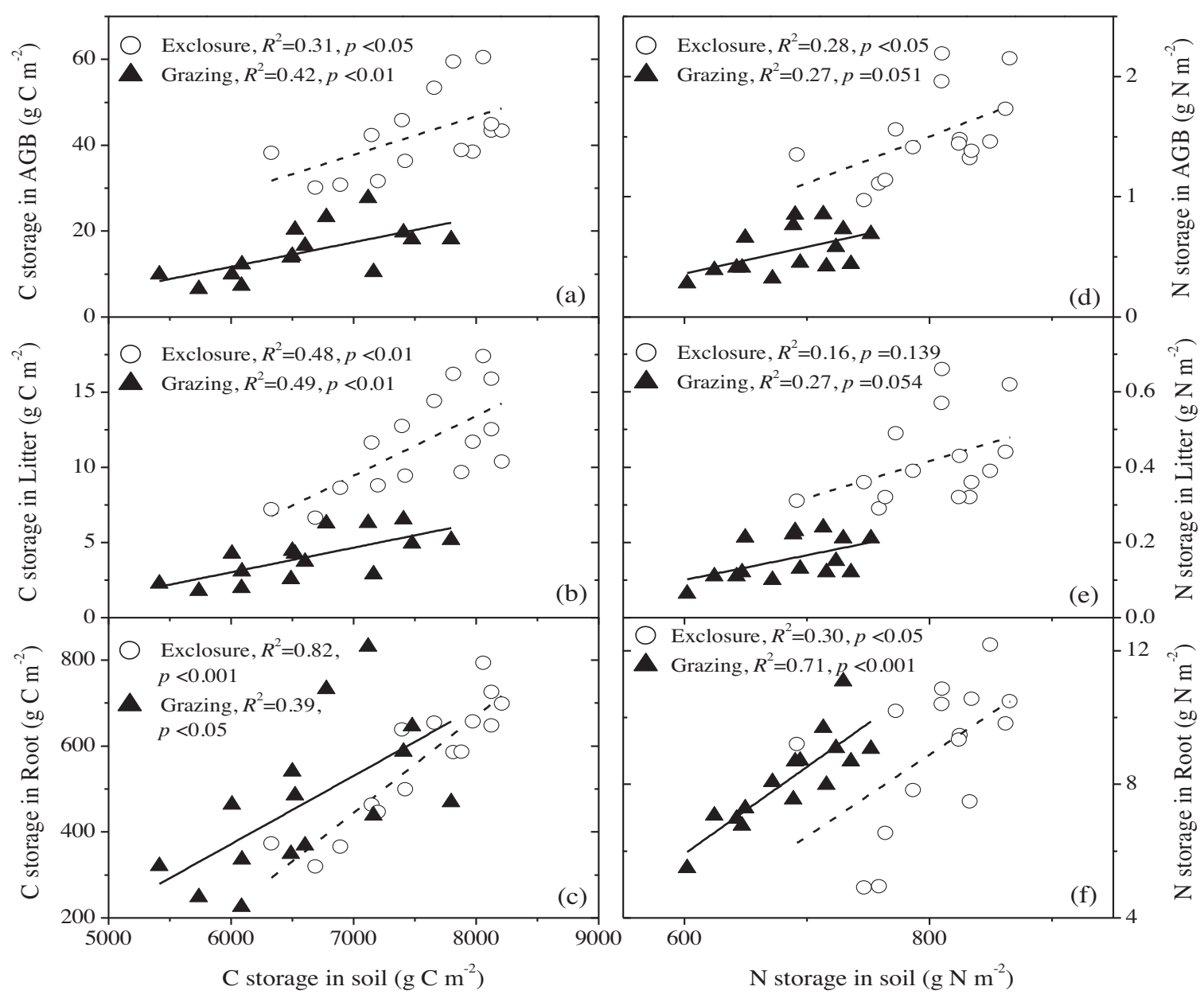

Fig. 5. Relationship between soil $\mathrm{C}(\mathrm{a}-\mathrm{c})$ and $\mathrm{N}(\mathrm{d}-\mathrm{f})$ storage and the storages in aboveground biomass (AGB), litter, root for grazing and exclosure sites.

observed that the $\mathrm{C}$ and $\mathrm{N}$ in roots were about $56-151 \%$ higher in long-term exclosure sites (more than 17 years) than in grazed grassland. Pineiro et al. (2009) reported that significantly lower belowground biomass in grazing sites as compared to the ungrazed sites was generally found at mesic regions ( $\sim 400-850 \mathrm{~mm}$ of mean annual precipitation). In our study, although grazing exclusion generally resulted in an increase of root biomass at all three experimental sites, no significant difference in root $\mathrm{C}$ and $\mathrm{N}$ storage was found between the exclosure and grazing plots, which might be partly due to the relatively low mean annual precipitation $(339 \mathrm{~mm})$ and short duration of exclusion (6 years).

In our study, both soil $\mathrm{C}$ and $\mathrm{N}$ concentration and storage were significantly increased after the exclusion of grazing, which is consistent with earlier publications (Luan et al., 2014; Mekuria et al., 2007; Pei et al., 2008 Zhou et al., 2011). The average soil $\mathrm{C}$ and $\mathrm{N}$ accumulation rates during the 6 years of exclosure were about $38.0 \mathrm{~g} \mathrm{C}$ and $4.8 \mathrm{~g} \mathrm{~N} \mathrm{~m}^{-2} 10 \mathrm{~cm}^{-1}$ year $^{-1}$, respectively, which were similar to values previously reported for grazing exclusion sites from semi-arid grasslands in northern China (Qiu et al., 2013; Wang et al., 2011 Zhou et al., 2011), and were compared well with the average for set-asides under the US Conservation Reserve Program (approximately $40.0 \mathrm{~g} \mathrm{C} \mathrm{m}^{-2} 10 \mathrm{~cm}^{-1}$ year $^{-1}$ ) (Ogle et al., 2003). Moreover, these accumulation rates were relatively higher than the losses of soil $\mathrm{C}$ and $\mathrm{N}$ from grassland due to long-term grazing or conversion to other land use types, ranging from 14 to $30 \mathrm{~g} \mathrm{C} \mathrm{m}^{-2} 10 \mathrm{~cm}^{-1}$ year $^{-1}$ and 0.4 to $1.3 \mathrm{~g} \mathrm{~N} \mathrm{~m}^{-2} 10 \mathrm{~cm}^{-1}$ year $^{-1}$, respectively (Cui et al., 2005; Ingram et al., 2008; Wang et al., 2012). These results indicate that grazing exclusion is an effective restoration approach to sequester $\mathrm{C}$ and $\mathrm{N}$ in soils and that the corresponding accumulation rates could be greater than the losses of soil $\mathrm{C}$ and $\mathrm{N}$ by human disturbances. However, some other studies reported that grazed sites might exhibit higher soil $\mathrm{C}$ and $\mathrm{N}$ storages or without a statistically significant difference as compared with adjacent ungrazed sites (Li et al., 2012; Shi et al., 2013; Shrestha and Stahl, 2008). These differences may be partly due to whether grazing pressure exceeds a site's carrying capacity, and whether it is sufficiently far beyond that capacity that it has crossed an ecological threshold (Sasaki et al., 2011). Additionally, the discrepancies in duration of exclosure, climatic conditions and original and post-grazing vegetation and soil properties from different studies were also found to cause the inconsistent results (Medina-Roldan et al., 2012; Reeder et al., 2004; Wang et al., 2011).

The estimated global sequestration rate of ecosystem $C$ for grassland, without consideration of the effects of grazing exclusion, ranges from 0.3 to $5.7 \mathrm{~g} \mathrm{C} \mathrm{m}^{-2}$ year $^{-1}$ (Lal, 2004; Qiu et al., 2013). However, as showed by this study, grazing exclusion could lead to an increase of total ecosystem $\mathrm{C}$ and $\mathrm{N}$ storages at rates of $173.6 \mathrm{~g} \mathrm{C} \mathrm{m}^{-2}$ year $^{-1}$ and $19.8 \mathrm{~g} \mathrm{~N} \mathrm{~m}^{-2}$ year $^{-1}$, respectively. These relatively higher values suggested that grazing exclusion may accelerate the restoration of ecosystem $\mathrm{C}$ and $\mathrm{N}$ storages, at least in degraded semi-arid grassland. However, it should be noted that soil plays the most important role, as most of the ecosystem $C$ and $\mathrm{N}$ are stored in the soil for grassland (Fig. 4). Moreover, the accumulation of $\mathrm{C}$ and $\mathrm{N}$ in soil contributed to more than $87.6 \%$ and $98.2 \%$ of the increases in ecosystem C and $\mathrm{N}$ storage, respectively, indicating that the restoration of ecosystem $\mathrm{C}$ and $\mathrm{N}$ were mainly due to the increase of $\mathrm{C}$ and $\mathrm{N}$ in soil after grazing exclusion (Li et al., 2012; Mekuria et al., 2011). 


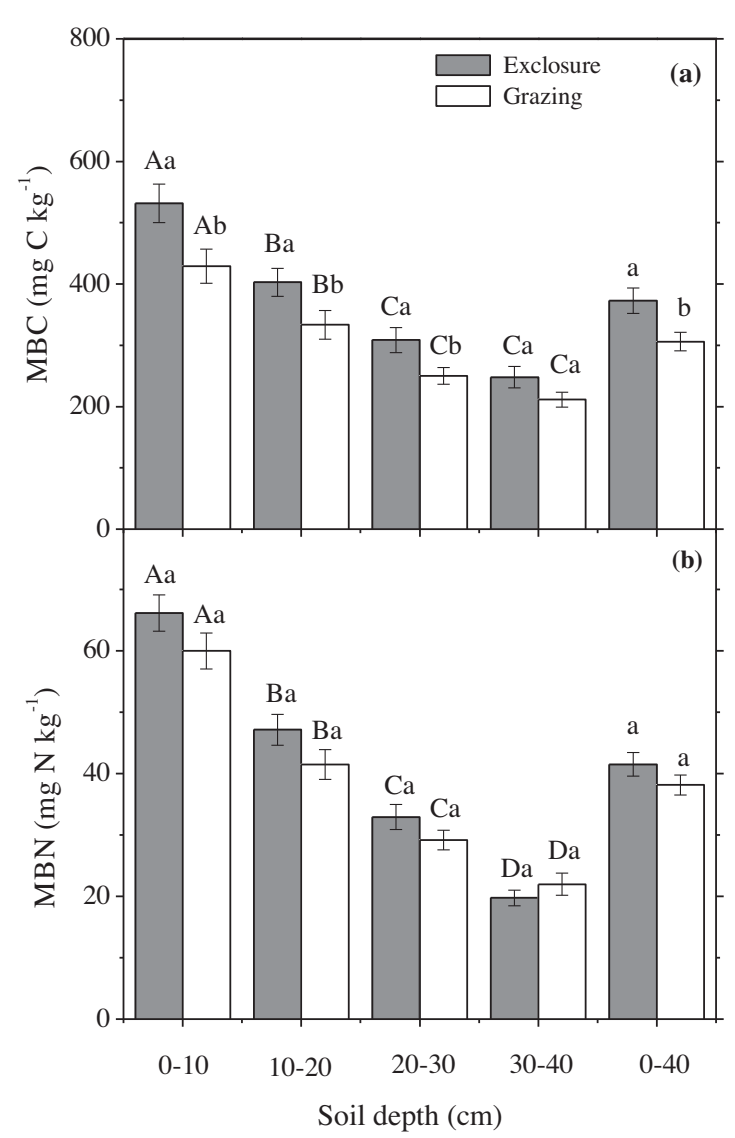

Fig. 6. The effects of grazing exclusion on MBC (a) and MBN (b) concentrations (mean $\pm \mathrm{SE}, N=15$ ) in different soil depths of grasslands. Uppercase letters indicate significant differences among different soil depths, Lowercase letters indicate significant differences between grazing and exclosure sites $(P<0.05)$.

Several potential mechanisms could be the reasons for the significant differences of ecosystem $\mathrm{C}$ and $\mathrm{N}$ storages between grazing and exclosure plots. Firstly, grazing exclusion might increase the grazing pressure on the remaining communal grazing lands, which in turn could cause a further decrease of $\mathrm{C}$ and $\mathrm{N}$ storage in grazing area (Mekuria et al., 2011). Additionally, the restoration of ecosystem $\mathrm{C}$ and $\mathrm{N}$ after grazing exclusion can be partly explained by the increased input and decreased loss of $\mathrm{C}$ and $\mathrm{N}$. On the one hand, grazing exclusion appears to have led to increased aboveground, litter and root biomass, which in turn might enhance the input of $\mathrm{C}$ and $\mathrm{N}$ into soil. Descheemaeker et al. (2006) observed an increase of organic matter input from $20 \mathrm{~g} \mathrm{~m}^{-2}$ in degraded grazing lands to approximately $600 \mathrm{~g} \mathrm{~m}^{-2}$ in 20 years exclosure site. The significant positive correlations of soil $\mathrm{C}$ and $\mathrm{N}$ storages with the $\mathrm{C}$ and $\mathrm{N}$ storages in plant biomass in our study

Table 3

Correlation between SOC, TN, C/N, MBC and $\mathrm{MBN}$ for different treatments (incorporating all depths, $N=60$ ).

\begin{tabular}{llllll}
\hline Treatment & Parameter & TN & C/N & MBC & MBN \\
\hline Exclosure & SOC & $0.959^{*}$ & $0.409^{*}$ & $0.859^{*}$ & $0.898^{*}$ \\
& TN & & 0.148 & $0.810^{*}$ & $0.909^{*}$ \\
& C/N & & & $0.367^{*}$ & 0.249 \\
& MBC & & & & $0.759^{*}$ \\
Grazing & SOC & $0.934^{*}$ & $0.487^{*}$ & $0.845^{*}$ & $0.831^{*}$ \\
& TN & & 0.152 & $0.796^{*}$ & $0.867^{*}$ \\
& C/N & & & $0.401^{*}$ & 0.194 \\
& MBC & & & & $0.723^{*}$ \\
\hline
\end{tabular}

Note: Asterisks indicate a significant correlation at $P<0.01$. also support the influence of organic matter input from vegetation to the soil. On the other hand, long-term grazing is known to stimulate soil mineralization, nitrification and ammonification (Giese et al., 2013; Hassink, 1994), which in turn could result in higher ecosystem respiration rates and $\mathrm{N}_{2} \mathrm{O}$ emissions (Giese et al., 2013; Polley et al., 2008). However, these losses of ecosystem $C$ and $\mathrm{N}$, as well as the outflow of energy and nutrient from the soil-plant system to livestock, are thought to be reduced when the disturbance is stopped by grazing exclusion (Qiu et al., 2013 Zhou et al., 2011).

\section{2. $M B N$ and $M B C$}

Soil microbial biomass is sensitive to soil resource availability and land management strategy (Liu et al., 2012; Wu et al., 2010). Although our results showed that exclusion of grazing did not significantly affect MBN, significant greater MBC were observed in the exclosure plots than in the grazing plots, which is in accordance with previous studies (Fließbach and Mader, 2000; Shrestha and Stahl, 2008). In typical grasslands of Inner Mongolia, Ma et al. (2005) also found almost 30\% higher MBC in ungrazed soil as compared with grazed soil, suggesting that higher organic matter inputs from root exudates and plant litter could enhance the MBC in the soil. Moreover, the MBC and MBN in both treatments were significantly decreased with soil depth in this study, which indicated a higher potential opportunity for nutrient availability and cycling in the upper soil depths relative to the deeper soils (Liu et al., 2012).

Additionally, our results showed that the fraction of SOC made up of microbial biomass ( $\mathrm{MBC} / \mathrm{SOC}$ ratio) was higher in the exclosure plots, suggesting that grazing exclusion could alter the quality of organic matter, probably leading to a more metabolically active microbial community and increased SOM decomposition (Kieft, 1994). Shrestha and Stahl (2008) also pointed out that the higher $\mathrm{MBC} / \mathrm{SOC}$ ratio in ungrazed soil might be due to greater amount of organic matter accumulating the soil and more suitable environment for microbial growth. However, the relatively lower $\mathrm{MBN} / \mathrm{TN}$, as well as the soil $\mathrm{C} / \mathrm{N}$ ratio, in exclosure plots than in grazing plots indicated that soil $\mathrm{N}$ availability and turnover might decrease after 6 years of grazing exclusion and $\mathrm{N}$ could be a limiting factor for $\mathrm{C}$ sequestration in our study area. Apart from the strong correlation between soil C and N, MBC and MBN also exhibited close relationship with SOC and TN in both grazing and exclosure plots, suggesting that soil microbial biomass was a sensitive indicator of the soil $\mathrm{C}$ and $\mathrm{N}$ dynamics.

\subsection{Implications for $C$ and $N$ storage in the RGLG project}

Overgrazing has been a primary contributor to grassland degradation and desertification (Ingram et al., 2008; Li et al., 2012; Mcsherry and Ritchie, 2013). The effect of grazing on C and $\mathrm{N}$ dynamics in semi-arid grassland has received considerable attention, but the restoration of ecosystem $\mathrm{C}$ and $\mathrm{N}$ storage after grazing exclusion has rarely been reported, especially referring to the RGLG project. Our results showed that grazing exclusion has a high potential to accelerate the restoration of ecosystem $\mathrm{C}$ and $\mathrm{N}$ storages and is an important alternative to stop further degradation. However, the existing literature on the effectiveness of grazing exclusion contains many inconsistent results. Pei et al. (2008) found a significant increase in SOC and TN after only 2 years of grazing exclusion in a desert steppe of northern China. However, Shrestha and Stahl (2008) reported no significant effect of longterm grazing exclusion (more than 40 years) on SOC in a semi-arid sagebrush steppe. In the present study, the ecosystem $\mathrm{C}$ and $\mathrm{N}$ accumulation rates during the 6 years of exclosure averaged $173.6 \mathrm{~g} \mathrm{C} \mathrm{m}^{-2}$ year $^{-1}$ and $19.8 \mathrm{~g} \mathrm{~N} \mathrm{~m}^{-2}$ year $^{-1}$, respectively. With 
these accumulations rates, approximately 20 years are needed to restore the degraded grasslands in the study area to a stable or mature condition in northern China in terms of productivity and $C$ and N storage (Bai et al., 2004; Qiu et al., 2013). He et al. (2008) also reported that a two decades' duration of grazing exclusion would be appropriate for restoring the degraded Leymus chinensis grasslands in northern China to state with similar productivity and $\mathrm{C}$ and $\mathrm{N}$ storage as compared to undisturbed natural grassland. However, this ecological restoration process could be even longer if the integrity of biological interaction between vegetation and soil, species diversity and soil quality are to be considered (He et al., 2008; Jing et al., 2014). Furthermore, some studies also indicated a maximum amount of $\mathrm{C}$ and $\mathrm{N}$ accumulation after certain period of exclosure and a relatively lower accumulation rate during the late stage of succession (Li et al., 2012; Qiu et al., 2013; Zhou et al., 2011 ). Therefore, we propose that grazing exclusion for at least two decades would be needed to restore the present degraded grasslands in terms of productivity and $\mathrm{C}$ and $\mathrm{N}$ storage, and suggest that more long-term studies are essential to evaluate the holistic effectiveness of the RGLG project for restoring degraded grasslands.

Moreover, some improved grassland management strategies need to be included in the RGLG project. For example, restrotational grazing system, which is important to optimize the quality and quantity of forage growth (Briske et al., 2008) and to alleviate the grazing pressure in the reduced area of communal grazing lands, should be rationally implemented in the RGLG project. Several previous studies showed that the aboveground biomass, species diversity and $\mathrm{C}$ and $\mathrm{N}$ storage might decrease during the mid- or late stage of succession because of the litter layer accumulation, light and water resources competition, and accelerated decomposition rates (He et al., 2008; Jing et al., 2014; Qiu et al., 2013). In addition, the $\mathrm{N}$ availability should be improved in the severely degraded grasslands, as our results showed that $\mathrm{N}$ could be a limiting factor for $\mathrm{C}$ sequestration in our study area. Furthermore, future conservation practices within the RGLG project should include both economical and biological considerations, as ecosystem $\mathrm{C}$ and $\mathrm{N}$ storage through grazing exclusion might have a relatively lower trade off with the present implementation costs.

\section{Conclusions}

Our results showed that the degraded grasslands in Hulunbuir region exhibited high potentials to sequester $\mathrm{C}$ and $\mathrm{N}$, and could be restored by the grazing exclusion. Exclusion of grazing for 6 years resulted in significant increases of plant biomass and soil $\mathrm{C}$ and $\mathrm{N}$ contents, leading to a substantial restoration of ecosystem $\mathrm{C}$ and $\mathrm{N}$ storage. Moreover, the relatively higher sequestration rates in our study suggested that grazing exclusion is a powerful tool for restoration of ecosystem $\mathrm{C}$ and $\mathrm{N}$ storages, at least in degraded semi-arid grassland. The soil played a more important role than biomass for $\mathrm{C}$ and $\mathrm{N}$ sequestration in grassland ecosystems. Soil $\mathrm{MBC}$ and MBN also increased following grazing exclusion, probably because of the enhanced organic matter inputs from plant litter and root exudates. The significant correlations between soil organic matter and microbial biomass suggested that soil microbial biomass could be a sensitive indicator of the soil $\mathrm{C}$ and $\mathrm{N}$ dynamics. Our results indicated that grazing exclusion within the RGLG project is an effective restoration approach to control grassland degradation and improve ecosystem service. However, our results also suggested that grazing exclusion for at least two decades would be needed to restore the present degraded grasslands in terms of productivity and $\mathrm{C}$ and $\mathrm{N}$ storage. These findings are potentially important because more than 60 million hectare degraded grasslands are included in the nationwide RGLG project.
Therefore, an important scientific priority has to be performed for more long-term experiments including different vegetation types and exclosure duration under different climatic conditions, and to conduct comprehensive multidisciplinary studies for sustainable grassland management practices.

\section{Acknowledgments}

This study was supported by the Strategic Priority Research Program of the Chinese Academy of Sciences (XDA05060103), the Ministry of Science and Technology of China (2012CB417103), the National Natural Science Foundation of China (41105117), and State Key Laboratory of Forest and Soil Ecology (LFSE2013-06). Special thanks go to the staffs from Monitoring Station for Eco-environment of Hulunbuir for their fruitful help in field sampling. The authors are grateful to the anonymous reviewers for providing critical comments and suggestions.

\section{References}

Bai, Y.F., Han, X.G., Wu, J.G., Chen, Z.Z., Li, L.H., 2004. Ecosystem stability and compensatory effects in the Inner Monglolia grassland. Nature 431, $181-184$.

Briske, D.D., Derner, J.D., Brown, J.R., Fuhlendorf, S.D., Teague, W.R., Havstad, K.M., Gillen, R.L., Ash, A.J., Willms, W.D., 2008. Rotational grazing on rangeland: reconciliation of perception and experimental evidence. Rangeland Ecol. Manage. 61, 3-17.

Cheng, J., Wu, G., Zhao, L., Li, Y., Li, W., Cheng, J., 2011. Cumulative effects of 20-year exclusion of livestock grazing on above- and belowground biomass of typical steppe communities in arid areas of the Loess Plateau, China. Plant Soil Environ. $57,40-44$.

Cui, X., Wang, Y., Niu, H., Wu, J., Wang, S., Schnug, E., Rogasik, J., Fleckenstein, J., Tang, Y., 2005. Effect of long-term grazing on soil organic carbon content in semiarid steppes in Inner Mongolia. Ecol. Res. 20, 519-527.

Descheemaeker, K., Muys, B., Nyssen, J., Poesen, J., Raes, D., Haile, M., Deckers, J., 2006. Litter production and organic matter accumulation in exclosures of the Tigray Highlands, Ethiopia. For. Ecol. Manage. 233, 21-35.

Fließbach, A., Mader, P., 2000. Microbial biomass and size-density fractions differ between soils of organic and conventional agricultural systems. Soil Biol. Biochem. 32, 757-768.

Follett, R.F., Reed, D.A., 2010. Soil carbon sequestration in grazing lands: societal benefits and policy implications. Rangeland Ecol. Manage. 63, 4-15.

Fornara, D.A., Tilman, D., 2012. Soil carbon sequestration in prairie grasslands increased by chronic nitrogen addition. Ecology 93, 2030-2036.

Gallaher, R.N., Weldon, C.O., Boswell, F.C., 1976. A semiautomated procedure for total nitrogen in plant and soil samples. Soil Sci. Soc. Am. J. 40, 887-889.

Giese, M., Brueck, H., Gao, Y., Lin, S., Steffens, M., Kogel-Knabner, I., Glindemann, T. Susenbeth, A., Taube, F., Butterbach-Bahl, K., Zheng, X., Hoffmann, C., Bai, Y., Han, $\mathrm{X}$. 2013. N balance and cycling of Inner Mongolia typical steppe: a comprehensive case study of grazing effects. Ecol. Monogr. 83, 195-219.

Hassink, J., 1994. Effects of soil texture and grassland management on soil organic C and $\mathrm{N}$ and rates of $\mathrm{C}$ and $\mathrm{N}$ mineralization. Soil Biol. Biochem. 26, 1221-1231.

He, N., Yu, Q., Wu, L., Wang, Y., Han, X., 2008. Carbon and nitrogen store and storage potential as affected by land-use in a Leymus chinensis grassland of northern China. Soil Biol. Biochem. 40, 2952-2959.

Ingram, L.J., Stahl, P.D., Schuman, G.E., Buyer, J.S., Vance, G.F., Ganjegunte, G.K., Welker, J.M., Derner, J.D., 2008. Grazing impacts on soil carbon and microbia communities in a mixed-grass ecosystem. Soil Sci. Soc. Am. J. 72, 939-948.

Jeddi, K., Chaieb, M., 2010. Changes in soil properties and vegetation following livestock grazing exclusion in degraded arid environments of South Tunisia. Flora 205, 184-189.

Jing, Z., Cheng. J., Su, J., Bai, Y., Jin, J., 2014. Changes in plant community composition and soil properties under 3-decade grazing exclusion in semiarid grassland. Ecol. Eng. 64, 171-178.

Kieft, T.L., 1994. Grazing and plant-canopy effects on semiarid soil microbial biomass and respiration. Biol. Fertil. Soils 18, 155-162.

Lal, R., 2004. Soil carbon sequestration impacts on global climate change and food security. Science 304, 1623-1627.

Lal, R., 2010. Managing soils and ecosystems for mitigating anthropogenic carbon emissions and advancing global food security. Bioscience 60, 708-721.

Li, Y., Zhou, X., Brandle, J.R., Zhang, T., Chen, Y., Han, J., 2012. Temporal progress in improving carbon and nitrogen storage by grazing exclosure practice in a degraded land area of China's Horqin Sandy Grassland. Agric. Ecosyst. Environ. 159, 55-61.

Liu, J., Diamond, J., 2005. China's environment in a globalizing world: how China and the rest of the world affect each other. Nature $435,1179-1186$.

Liu, N., Zhang, Y., Chang, S., Kan, H., Lin, L., 2012. Impact of grazing on soil carbon and microbial biomass in typical steppe and desert steppe of Inner Mongolia. PLoS One 7, e36434. 
Luan, J., Cui, L., Xiang, C., Wu, J., Song, H., Ma, Q., Hu, Z., 2014. Different grazing removal exclosures effects on soil $C$ stocks among alpine ecosystems in east Qinghai-Tibet Plateau. Ecol. Eng. 64, 262-268.

Ma, X., Wang, Y., Wang, S., Wang, J., Li, C., 2005. Impacts of grazing on soil carbon fractions in the grasslands of Xilin River Basin, Inner Mongolia. Acta Phytoecol. Sinica 29, 569-576.

Mcsherry, M.E., Ritchie, M.E., 2013. Effects of grazing on grassland soil carbon: a global review. Global Change Biol. 19, 1347-1357.

Medina-Roldan, E., Paz-Ferreiro, J., Bardgett, R.D., 2012. Grazing exclusion affects soil and plant communities: but has no impact on soil carbon storage in an upland grassland. Agric. Ecosyst. Environ. 149, 118-123.

Mekuria, W., Veldkamp, E., Haile, M., Nyssem, J., Muys, B., Gebirehiwot, K., 2007. Effectiveness of exclosures to restore degraded soils as a result of overgrazing in Tigray, Ethiopia. J. Arid Environ. 69, 270-284.

Mekuria, W., Veldkamp, E., Corre, M.D., Haile, M., 2011. Restoration of ecosystem carbon stocks following exclosure establishment in communal grazing lands in Tigray, Ethiopia. Soil Sci. Soc. Am. J. 75, 246-256.

Nelson, D.W., Sommers, L.E., 1982. Total carbon, organic carbon, and organic matter, In: Page, A.L., Miller, R.H., Keeney, D.R. (Eds.), Methods of Soil Analysis, Part 2. second ed. American Society of Agronomy, Madison, pp. 539-572.

Ni, J., 2002. Carbon storage in grasslands of China. J. Arid Environ. 50, 205-218.

Ogle, S., Breidt, F., Eve, M., Paustian, K., 2003. Uncertainty in estimating land use and management impacts on soil organic carbon storage for US agricultural lands between 1982 and 1997. Global Change Biol. 9, 1521-1542.

Pei, S.F., Fu, H., Wan, C.G., 2008. Changes in soil properties and vegetation following exclosure and grazing in degraded Alax desert steppe of Inner Mongolia, China. Agric. Ecosyst. Environ. 124, 33-39.

Pineiro, G., Paruelo, J.M., Jobbagy, E.G., Jackson, R.B., Oesterheld, M., 2009. Grazing effects on belowground $\mathrm{C}$ and $\mathrm{N}$ stocks along a network of cattle exclosures in temperate and subtropical grasslands of South America. Global Biogeochem. Cycles 23 (GB2003) doi:http://dx.doi.org/10.1029/2007GB003168.

Pineiro, G., Paruelo, J.M., Oesterheld, M., Jobbagy, E.G., 2010. Pathways of grazing effects on soil organic carbon and nitrogen. Rangeland Ecol. Manage. 63, 109-119.

Polley, H.W., Frank, A.B., Sanabria, J., Phillips, R.L., 2008. Interannual variability in carbon dioxide fluxes and flux-climate relationships on grazed and ungrazed northern mixed-grass prairie. Global Change Biol. 14, 1620-1632.

Qiu, L., Wei, X., Zhang, X., Cheng, J., 2013. Ecosystem carbon and nitrogen accumulation after grazing exclusion in semiarid grassland. PLoS One 8, e55433.
Reeder, J.D., Schuman, G.E., Morgan, J.A., Lecain, D.R., 2004. Response of organic and inorganic carbon and nitrogen to long-term grazing of the shortgrass steppe. Environ. Manage. 33, 485-495.

Sasaki, T., Okubo, S., Okayasu, T., Jamsran, U., Ohkuro, T., Takeuchi, K., 2011. Indicator species and functional groups as predictors of proximity to ecological thresholds in Mongolian rangelands. Plant Ecol. 212, 327-342.

Scurlock, J.M.O., Hall, D.O., 1998. The global carbon sink: a grassland perspective. Global Change Biol. 4, 229-233.

Shi, X., Li, X., Li, C., Shang, Z., Ma, Q., 2013. Grazing exclusion decreases soil organic C storage at an alpine grassland of Qinghai-Tibetan Plateau. Ecol. Eng. 57, 183-187.

Shrestha, G. Stahl, P.D., 2008. Carbon accumulation and storage in semi-arid sagebrush steppe: effects of long-term grazing exclusion. Agric. Ecosyst. Environ. 125, 173-181.

Vance, E.D., Brookes, P.C., Jenkinson, D.S., 1987. Microbial biomass measurements in forest soils: determination of $k_{c}$ values and tests of hypothesis to explain the failure of the chloroform fumigation-incubation method in acid soils. Soil Biol. Biochem. 19, 689-696.

Wang, S., Wilkes, A., Zhang, Z., Chang, X., Lang, R., Wang, Y., Niu, H., 2011. Management and land use change effects on soil carbon in northern China's grasslands: a synthesis. Agric. Ecosyst. Environ. 142, 329-340.

Wang, X., Yan, Y., Cao, Y., 2012. Impact of historic grazing on steppe soils on the northern Tibetan Plateau. Plant Soil 354, 173-183.

Ward, S.E., Bardgett, R.D., McNamara, N.P., Adamson, J.K., Ostle, N.J., 2007. Long-term consequences of grazing and burning on northern peatland carbon dynamics. Ecosystems 10, 1069-1083.

Wu, X., Yao, Z., Brüggemann, N., Shen, Z., Wolf, B., Dannenmann, M., Zheng, X., Butterbach-Bahl, K., 2010. Effects of soil moisture and temperature on $\mathrm{CO}_{2}$ and $\mathrm{CH}_{4}$ soil-atmosphere exchange of various land use/cover types in a semi-arid grassland in Inner Mongolia, China. Soil Biol. Biochem. 42, 773-787.

Wu, X., Liu, G., Butterbach-Bahl, K., Fu, B., Zheng, X., Brüggemann, N., 2013. Effects of land cover and soil properties on denitrification potential in soils of two semiarid grasslands in Inner Mongolia, China. J. Arid Environ. 92, 98-101.

Xiong, D., Shi, P., Sun, Y., Wu, J., Zhang, X., 2014. Effects of grazing exclusion on plant productivity and soil carbon nitrogen storage in alpine meadows in northern Tibet, China. Chin. Geogr. Sci. 24, 488-498.

Zhou, Z., Li, F., Chen, S., Zhang, H., Li, G., 2011. Dynamics of vegetation and soil carbon and nitrogen accumulation over 26 years under controlled grazing in a desert shrubland. Plant Soil 341, 257-268. 